\title{
Effectiveness of nursing interventions in the postoperative recovery of gastric cancer patients: a systematic literature review
}

\author{
Eficácia das intervençóes de enfermagem na recuperação pós-operatória de pessoas com \\ cancro gástrico: revisão sistemática literatura
}

Eficacia de las intervenciones de enfermería en la recuperación postoperatoria en pacientes con cáncer gástrico: revisión sistemática de la literatura

Noélia Cristina Rodrigues Pimenta Gomes*; Célia Samarina Vilaça de Brito Santos**;

Maria Merícia Gouveia Rodrigues Bettencourt de Jesus***; Marco António da Silva Henriques****

\begin{abstract}
Context: Gastric cancer is a global health problem and surgery is the most common curative treatment.

Objectives: To analyze and synthesize the nursing programs/interventions and their effectiveness in the postoperative recovery of gastric cancer patients.

Review Method: Using a PICO guiding question, a literature review was conducted on articles exploring the effectiveness of nursing programs/interventions in the postoperative recovery of gastric cancer patients aged 18 years or more and published between 2005 and 2015. A search was performed in the CINAHL $®$, Cochrane Central Register of Controlled Trials, MedicLatina, and MEDLINE® databases. The methodological quality was assessed based on the recommendations of the Joanna Briggs Institute ${ }^{\circledR}$.

Interpretation of Results: Three studies were included, which support the effectiveness of nursing interventions in reducing patients' functional and nutritional decline, and improving their cognitive function, knowledge, and ability to cope with the disease. Conclusion: The nursing programs/interventions contribute to the postoperative recovery of gastric cancer patients. Further studies should be conducted to consolidate these results.
\end{abstract}

Keywords: gastric cancer; surgical procedures, operative; gastrectomy; nursing

\section{Resumo}

Contexto: O cancro gástrico é um problema mundial de saúde, sendo a intervenção cirúrgica a mais frequente forma de tratamento curativo. Objetivos: Analisar e sintetizar os programas/intervenções de enfermagem e a sua eficácia na recuperação pós-operatória de pessoas com cancro gástrico.

Método de Revisão: Utilizando como referência uma questão PICO, realizou-se a revisão dos artigos publicados entre 2005 e 2015, que avaliaram a eficácia dos programas/intervenções de enfermagem na recuperação pós-operatória das pessoas com cancro gástrico, com idade superior ou igual a 18 anos. Pesquisou-se nas bases de dados: CINAHL®, Cochrane Central Register of Controlled Trials, MedicLatina e MEDLINE®. Qualidade metodológica foi avaliada segundo as recomendações do Instituto Joanna Briggs ${ }^{\circledR}$.

Interpretação dos Resultados: Três estudos foram incluídos, os quais sustentam a eficácia das intervenções na redução do declínio funcional e nutricional, melhoria da função cognitiva, conhecimento e capacidade de lidar com a doença.

Conclusão: Os programas/intervenções de enfermagem contribuem para a recuperação pós-operatória das pessoas com cancro gástrico. Recomenda-se o reforço da investigação para fortalecer os resultados encontrados.

Palavras-chave: neoplasias gástricas; procedimentos cirúrgicos, gastrectomia; enfermagem

\footnotetext{
* MSc., Adjunct Professor, Escola Superior de Enfermagem São José de Cluny, 9050-535 Funchal, Portugal [noeliapimenta@gmail.com]. Address for correspondence: Caminho Da Quinta De Sant'Ana, 71, 9200-075, writing.

*** Ph.D., Coordinating Professor, Nursing School of Porto, 4200-072, Porto, Portugal [celiasantos@esenf.pt]. Contribution to the article: guidance for the SLR methodology, and data analysis and discussion

*** Ph.D., Coordinating Professor, Escola Superior de Enfermagem São José de Cluny, 9050-535 Funchal Portugal [mbettencourt@esesicluny.pt. Contribution to the article: guidance for the SLR methodology, and data analysis and discussion.

***** MSc., Assistant Professor, Escola Superior de Enfermagem São José de Cluny, 9050-535 Funchal, Portugal [mhenriques@esesicluny.pt]. Contribution to the article: selection of articles, methodological quality
} assessment of the articles, and data extraction.

\section{Resumen}

Contexto: El cáncer gástrico es un problema de salud mundial y la cirugía es la forma más común de tratamiento curativo.

Objetivos: Analizar y sintetizar los programas/as intervenciones de enfermería y su eficacia en la recuperación postoperatoria de pacientes con cáncer gástrico.

Método de revisión: Utilizando como referencia una pregunta PICO, se realizó una revisión de los artículos publicados entre 2005 y 2015, que evaluaron la eficacia de los programas/as intervenciones de enfermería en la recuperación postoperatoria de los pacientes con cáncer gástrico mayores de 18 años. Se hicieron búsquedas en las bases de datos: CINAHL $®$, Cochrane Central Register of Controlled Trials, Cochrane Database of Systematic Reviews, MedicLatina y MEDLINE@. La calidad metodológica se evaluó de acuerdo con las recomendaciones del Instituto Joanna Briggs@

Interpretación de los resultados: Se incluyeron tres estudios, los cuales apoyan la eficacia de las intervenciones para reducir el deterioro funcional y nutricional, la mejora de la función cognitiva, el conocimiento y la capacidad de hacer frente a la enfermedad. Conclusión: Los programas/las intervenciones de enfermería contribuyen a la recuperación postoperatoria de pacientes con cáncer gástrico. Se recomienda reforzar la investigación para fortalecer nuestros resultados.

Palabras clave: cáncer gástrico; procedimientos quirúrgicos, gastrectomía; enfermería

Received for publication: 01.07 .16

Accepted for publication: 23.11 .16 


\section{Introduction}

Gastric cancer is a global health problem, and it is one of the few malignant neoplasms with geographical differences in terms of incidence, pathology, treatment, and evolution. Although its incidence has been declining in the Western hemisphere, steady rates have been reported in Eastern countries, particularly South Korea and Japan (Yamamoto, Rashid, \& Wong, 2015).

The International Agency for Research on Cancer (International Agency for Research on Cancer, World Health Organization, 2014) estimates that, in 2012, approximately 1 million new cases of gastric cancer and 720,000 deaths occurred worldwide, with a higher incidence in Asia, Latin America, and Eastern Europe. In 2012, about 734,000 of gastric cancer cases were attributable to Helicobacter pylori infection, which is the cause of $80 \%$ of cases of stomach cancer.

For the American Cancer Society (2014), stomach cancer or gastric cancer is a cancer that starts in the stomach and tends to develop slowly over the years. Before a true cancer develops, pre-cancerous changes often occur in the inner lining of the stomach.

There are currently four primary strategies available for cancer treatment: surgery, chemotherapy, radiotherapy, and biotherapy. According to DiazNieto, Orti-Rodríguez, and Winslet (2013), Laporte, Weston, Paludo, Castria, and Kalil (2014), and Mello, Lucena, Echer, and Luzia (2010), surgery is the initial treatment choice because, given the advancement in surgical techniques, it is the only curative treatment of gastric cancer. However, it should be noted that survival rates are still low and, in order to improve these results, chemotherapy after surgery may be recommended.

The surgical removal of the stomach is the most common curative treatment in gastric cancer patients; hence, Park and Park (2010) argue that it is important to develop guidelines for these patients' pre and postoperative care. Mello et al. (2010) also emphasize the importance of nurses' intervention in providing guidance/educating patients and their families and that this intervention should start in the preoperative period and continue throughout treatment, including the late postoperative period. Patients and their families need help for accepting the disease and deciding on treatment options, as well as information to promote the patient's recovery.
Based on the scientific evidence, the design and implementation of nursing programs/interventions in the perioperative period of patients undergoing gastric cancer surgery will contribute to improving nursing interventions and the patients' recovery. A preliminary search in the Cochrane Database of Systematic Reviews (CDSR) revealed that there are no systematic reviews exclusively focused on the effectiveness of nursing interventions in the postoperative recovery of adult gastric cancer patients undergoing surgical treatment.

Thus, this systematic literature review (SLR) was conducted based on the PICO (Population, Intervention, Comparison, and Outcome) model (Joanna Briggs Institute, 2014): population adults aged 18 years or more, with gastric cancer, undergoing surgical treatment; intervention - nursing interventions; comparison - does not apply; outcome - postoperative recovery (fewer complications, increased self-management skills, and improved quality of life), considering the evidence by Diaz-Nieto, Orti-Rodríguez, and Winslet (2013), Laporte et al. (2014), Mello et al. (2010), and Park and Park (2010). The following question guided this review: Which nursing interventions/programs are more effective in the postoperative recovery (fewer complications, increased self-management skills, and improved quality of life) of gastric cancer patients undergoing surgical treatment?

The main purpose of this study was to analyze and synthesize nursing programs/interventions and their effectiveness in the postoperative recovery (fewer complications, increased self-management skills, and improved quality of life) of gastric cancer patients undergoing surgical treatment.

\section{Systematic Review Method}

The systematic review began with the formulation of the question based on the PICO strategy - Population, Intervention, Comparison, and Outcome (Joanna Briggs Institute, 2014). Inclusion criteria (Table 1) were defined to guide the search and select the relevant literature of interest to the intended outcomes and the formulated question. In addition to the criteria shown in Table 1, we also took into account the publication date: (January 2005 and June 2015 and the language (Portuguese, Spanish, or English). 
Table 1

Inclusion Criteria

\begin{tabular}{ll}
\hline & Inclusion criteria \\
\hline Type of participants & This review will consider adults above 18 years of age.People aged 18 years or more \\
& with gastric cancer \\
Type of intervention(s)/ Phenomena of & The intervention of interest is magnesium in doses of at least two grams compared \\
interest & to placeboStudies on nursing programs/interventions implemented in the periop- \\
& erative period toward gastric cancer patients \\
Type of studies & - Randomized and non-randomized clinical trials \\
& - Cohort or prospective \\
& - Case-control or retrospective \\
& - Cross-sectional \\
& - Case reports and case studies \\
& Postoperative recovery (fewer complications, increased self-management skills, and \\
& improved quality of life). \\
\hline
\end{tabular}

\section{Strategy for search and identification of studies}

The following databases will be searched for published studies:The search was performed in the CINAHL ${ }^{\circledR}$ Plus, Cochrane Central Register of Controlled Trials, MedicLatina(tm) and MEDLINE® online databases. We used Websites of relevant organizations in each country including Kidney Health Australia, Kidney Health New Zealand and The Kidney Foundation of Cana the Medical Subject Headings (MeSH Browser $\left({ }^{\circledR}\right)$ and DeCS ${ }^{\circledR}$ to define the search terms, and a logical structure combining search terms, Boolean operators, and PICO components as search strategy. The following keywords were used in the search: Stomach Neoplasms; Gastric Cancer; Surgical Procedures, Operative; Gastrectomy; Advanced Practice Nursing; Intervention Studies; Nursing; Programs; Education.

The following Boolean strings were used: (Stomach Neoplasms OR gastric cancer) AND (Surgical Procedures, operative); (Stomach Neoplasms OR gastric cancer) AND (Advanced Practice Nursing); (Stomach Neoplasms OR gastric cancer) AND (Intervention Studies); (Stomach Neoplasms OR gastric cancer) AND (Nursing); (Stomach Neoplasms OR gastric cancer) AND (Education Program); (Stomach Neoplasms OR gastric cancer) AND (Nursing practice); (Gastrectomy And Nursing).

The method for study selection was based on whether the title and abstract of the articles included or not the search terms.

The studies were selected by two independent reviewers in two phases. Relevance tests were conducted in accordance with the recommendations of Pereira and Bachion (2006). A Relevance Test I (preliminary) was used with the purpose of refining the initial selection of articles (title and abstract reading). The studies selected in the Relevance Test I were again assessed in the Relevance Test II (full-text reading).

\section{Assessment of the methodological quality of the studies}

In this review, two reviewers assessed the methodological quality of the studies using the instruments recommended by the Joanna Briggs Institute (2011), adapted by Araújo (2014), namely the "Meta-Analysis of Statistics Assessment and Review Instrument (MAStARI) critical appraisal tools Comparable Cohort/Case Control Studies" and the "MAStARI critical appraisal tools Descriptive/Case Series Studies". The "MAStARI critical appraisal tools Randomized Control / Pseudo-randomized Trial" was also used. High or moderate quality studies (score higher than 7 or between 4 and 6 , respectively) were included. Low quality studies were excluded.

\section{Data extraction}

Data were extracted and discussed by two independent reviewers to reach a consensus. Data extraction was based on the guidelines of the Joanna Briggs Institute (2014), adapted by Araújo (2014), taking into account the title, authors, year and place where the study was developed, methodological guidelines, objectives, participants, ethical aspects, intervention performed, statistical tests, outcomes, and conclusion of the articles. The items were compiled in a table with the purpose of proceeding to the narrative summary of the data. 


\section{Data synthesis}

In this study, the narrative summary of quantitative data was performed since the included studies showed a great variability in terms of interventions and population. For this reason, they could not be grouped in order to meet the conditions necessary for the meta-analysis.

\section{Presentation of results}

Considering the methods described, the search results were refined depending on the criteria established until we reached the number of articles included in this review. Figure 1 shows the flow chart describing the steps taken until we reached the number of articles included.

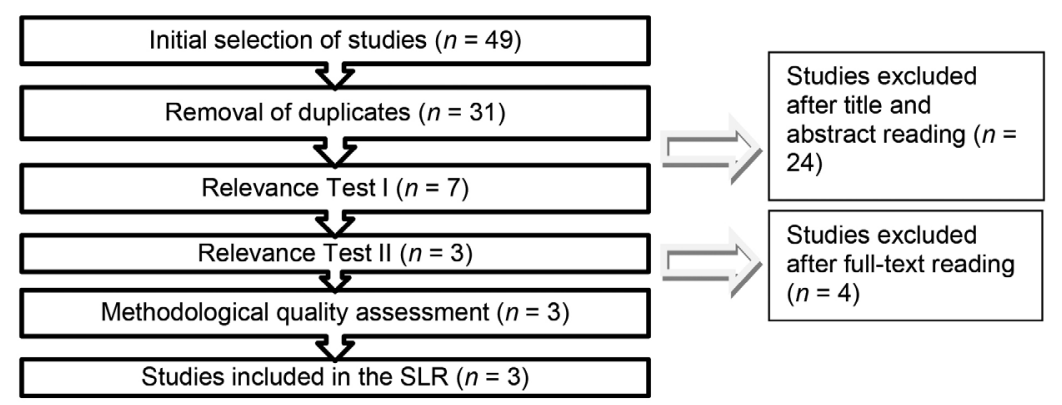

Figure 1. Flowchart of the search for the systematic literature review.

Three studies were selected for assessment of the methodological quality: a pilot clinical trial (nonrandomized), a prospective study with a controlled clinical trial, and a descriptive and comparative study. With regard to the methodological quality,

Table 2 we found one high quality study and two moderate quality studies. None of the articles had low quality, and all of them passed in the methodological quality assessment test (Table 2).

Articles according to the JBI methodological quality score

\begin{tabular}{llll}
\hline Study code & Author(s) - (Year) - Country & Study design & $\begin{array}{l}\text { JBI Methodological Quality } \\
\text { Score }\end{array}$ \\
\hline \multirow{2}{*}{ S 23 } & Chen, C. C-H, Lin, M-T, Tien, Y-W, Yen, C-J, & Clinical pilot trial (non- & 6 Points \\
& Huang, G-H, \& Inouye, SK. (2011) - Thailand & randomized) & Moderate quality \\
S 27 & Faller, H., Koch, GF., Reusch, A., Pauli, P., \& & Prospective study with con- & 7 Points \\
& Allgayer, H. (2009) - Germany & trolled clinical trial & High quality \\
S 29 & $\begin{array}{l}\text { Ahn, H. S., Yook, J. H., Park, Ch. H., Park, Y. K., } \\
\text { Wansik, Y., Lee, M-S., ... Yang, H-K. (2011) - Ko- }\end{array}$ & $\begin{array}{l}\text { Descriptive and comparative } \\
\text { rea and Japan }\end{array}$ & 4 points \\
& & & Moderate quality \\
\hline
\end{tabular}

Table 3 summarizes the most relevant results to the of the studies. topic under analysis based on the critical appraisal 
Table 3

Summary of the data extracted after critical appraisal of the studies

\begin{tabular}{|c|c|c|c|c|c|}
\hline Study & Author (s)/ & $\begin{array}{l}\text { Objective and } \\
\text { participants }\end{array}$ & Intervention & Results & Conclusions \\
\hline $\begin{array}{l}\text { Modified Hospital } \\
\text { Elder Life Program: } \\
\text { Effects on Abdomi- } \\
\text { nal Surgery Patients } \\
\text { S } 23\end{array}$ & Chen et al. & $\begin{array}{l}\text { To identify the ef- } \\
\text { fects of the Modified } \\
\text { Hospital Elder Life } \\
\text { Program (HELP) on } \\
\text { patients undergoing } \\
\text { elective abdominal } \\
\text { surgical procedures. } \\
\text { Experimental (102) } \\
\text { and control (77) } \\
\text { groups. Participants } \\
\text { were recruited } \\
\text { between August } 2007 \\
\text { and April } 2009 \text {. }\end{array}$ & $\begin{array}{l}\text { Modified HELP } \\
\text { Program: Early } \\
\text { mobilization; } \\
\text { Nutritional } \\
\text { assistance and } \\
\text { Therapeutic } \\
\text { cognitive activi- } \\
\text { ties }\end{array}$ & $\begin{array}{l}\text { Patients in the HELP group } \\
\text { (experimental group) } \\
\text { showed a significantly lower } \\
\text { decline on the performance } \\
\text { of activities of daily living } \\
\text { and nutritional status ( } p \\
<.001 \text { ) than the control } \\
\text { group; the delirium rate } \\
\text { was also lower in the HELP } \\
\text { group (0\%) than in the } \\
\text { control group }(16.7 \% ; p< \\
.001) \text {. }\end{array}$ & $\begin{array}{l}\text { The HELP program } \\
\text { effectively reduced } \\
\text { the patients' } \\
\text { functional decline, } \\
\text { nutritional status, } \\
\text { and postoperative } \\
\text { cognitive dysfunc- } \\
\text { tion (delirium). }\end{array}$ \\
\hline $\begin{array}{l}\text { Effectiveness of edu- } \\
\text { cation for gastric } \\
\text { cancer patients: a } \\
\text { controlled prospec- } \\
\text { tive trial compar- } \\
\text { ing interactive } \\
\text { vs. lecture-based } \\
\text { programs } \\
\text { S } 27\end{array}$ & Faller et al. & $\begin{array}{l}\text { To compare the } \\
\text { impact of an inter- } \\
\text { active program to } \\
\text { a lecture-based, } \\
\text { information-only } \\
\text { program in gastric } \\
\text { cancer patients. } \\
121 \text { patients: } 61 \\
\text { received an interac- } \\
\text { tive program and } 60 \\
\text { received a lecture- } \\
\text { based, information- } \\
\text { only program. } \\
\text { Participants were } \\
\text { recruited between } \\
\text { April } 2003 \text { and No- } \\
\text { vember } 2005 \text {. }\end{array}$ & $\begin{array}{l}\text { Interactive Edu- } \\
\text { cation Program } \\
\text { (interaction } \\
\text { allowed, both } \\
\text { among patients } \\
\text { and between } \\
\text { patients and } \\
\text { the educator). } \\
\text { The programs } \\
\text { included in- } \\
\text { formation on } \\
\text { gastric cancer, } \\
\text { post-surgical } \\
\text { disorders, } \\
\text { symptom } \\
\text { management, } \\
\text { strategies for } \\
\text { eating and } \\
\text { drinking, etc. }\end{array}$ & $\begin{array}{l}\text { Patients' disease-related } \\
\text { knowledge was significantly } \\
\text { higher in the interactive } \\
\text { group during hospitaliza- } \\
\text { tion }\left(\eta^{2}=0.14 \text { ) and was }\right. \\
\text { maintained at the } 6 \text { - and } \\
12 \text {-months follow-up ( } \eta^{2}= \\
0.05 ; \eta^{2}=0.10 \text { ). } \\
\text { With regard to the process } \\
\text { of actively coping with the } \\
\text { condition and quality of life, } \\
\text { patients coped better with } \\
\text { the illness during hospital- } \\
\text { ization ( } \eta^{2}=0.04 ; \text { QoL, } \\
\left.\eta^{2}=0.05\right) \text {, but not at the } \\
\text { follow-up. }\end{array}$ & $\begin{array}{l}\text { Interactive } \\
\text { education after } \\
\text { surgical treatment } \\
\text { improved gastric } \\
\text { cancer patients' } \\
\text { disease-related } \\
\text { knowledge, coping } \\
\text { skills, and quality } \\
\text { of life. }\end{array}$ \\
\hline $\begin{array}{l}\text { General periopera- } \\
\text { tive management } \\
\text { of gastric cancer } \\
\text { patients at bigh- } \\
\text { volume centers } \\
\text { S } 29\end{array}$ & Ahn et al. & $\begin{array}{l}\text { To compare the } \\
\text { general perioperative } \\
\text { management of gas- } \\
\text { tric cancer patients } \\
\text { at high-volume cen- } \\
\text { ters (over } 200 \text { cases/ } \\
\text { year) in Korea and } \\
\text { Japan; to contribute } \\
\text { to the improvement } \\
\text { of surgical outcomes } \\
\text { and to the develop- } \\
\text { ment of site-specific } \\
\text { protocols. } \\
\text { Surgeons and pa- } \\
\text { tients of Korean and } \\
\text { Japanese hospitals. }\end{array}$ & $\begin{array}{l}\text { Nursing inter- } \\
\text { ventions includ- } \\
\text { ed: insertion/ } \\
\text { maintenance } \\
\text { of a nasogastric } \\
\text { tube, patient } \\
\text { empowerment } \\
\text { for pain self- } \\
\text { management, } \\
\text { initiation of diet } \\
\text { and respec- } \\
\text { tive education } \\
\text { program, and } \\
\text { duration of } \\
\text { maintenance } \\
\text { of abdominal } \\
\text { drain tubes. }\end{array}$ & $\begin{array}{l}\text { A Levin tube and an ab- } \\
\text { dominal drain tube were } \\
\text { inserted in seven and } 10 \\
\text { hospitals, respectively; pain } \\
\text { management was ensured } \\
\text { through patient-controlled } \\
\text { anesthesia (PCA) until post- } \\
\text { operative day } 2 \text { or } 3 \text {. Water } \\
\text { ingestion was resumed up } \\
\text { to postoperative day } 3 \text { in } 12 \\
\text { hospitals, and } \\
\text { only one hospital provided } \\
\text { an education program } \\
\text { with the participation of a } \\
\text { surgeon, an oncologist, a } \\
\text { nurse, and a nutritionist. }\end{array}$ & $\begin{array}{l}\text { Nursing interven- } \\
\text { tions improved } \\
\text { postoperative } \\
\text { surgical outcomes, } \\
\text { regardless of the } \\
\text { postoperative } \\
\text { hospital length of } \\
\text { stay. }\end{array}$ \\
\hline
\end{tabular}

\section{Interpretation of the Results}

Two studies were conducted in Asia (Thailand, Korea and Japan) and one in Europe (Germany); the scarce geographical variability puts into evidence the importance attributed by these countries to this issue. This finding is consistent with other studies, namely in Yamamoto et al. (2015), who mention that, 
although the incidence of gastric cancer has been declining in the Western hemisphere, steady rates have been reported in Eastern countries, particularly South Korea and Japan.

The articles were published between 2009 and 2011. With regard to the methodological quality score, one of the articles had high quality (S27) and two had moderate quality (S23 and S29). S23 did not mention if the experimental groups were randomly selected or if any participant withdrew from the study, as recommended by the "MAStARI critical appraisal tools Randomized Control/Pseudo-randomized Trial"; S29 did not provide a clear description of the sample and the participant follow-up period. S27 met the criteria proposed by the "MAStARI critical appraisal tools Comparable Cohort/Case Control Studies" with the exception of the sample representativeness and the lack of clarity about the factors that could lead to bias. This SLR had the following limitations: its heterogeneity and the impossibility of conducting a meta-analysis.

The three studies included in the SLR confirm the effectiveness of nursing interventions/programs in the postoperative recovery of people with gastric cancer. In S23 and S29, they proved to be effective in reducing complications, and in S27 they effectively promoted self-management skills and improved quality of life. Therefore, we have chosen to emphasize the effectiveness of different nursing interventions/programs by aggregating them based on the obtained results.

\section{Reduction of postoperative complications}

The organized and systematic implementation of nursing interventions in the pre- and postoperative period can be effective in improving surgical outcomes (S29), as well as in detecting and allowing the early intervention in possible postoperative complications, namely by providing help to perform activities of daily living, maintain the nutritional status, and improve the cognitive function (S23).

When analyzing nursing interventions targeting gastric cancer patients in 14 centers, Ahn et al. (2011; S29) found similar interventions in the hospitals, except for the length of hospital stay. The authors emphasized that the information obtained can help set up protocols and consequently improve surgical outcomes. This studyinvolved surgeons whodescribed some interventions, including nursing interventions implemented in the pre and postoperative period such as the insertion/maintenance of a nasogastric tube, the patient's empowerment for pain selfmanagement, initiation of diet and corresponding education/support program, etc.

Mental alterations, namely confusion, delirium, and agitation, are among the most common postoperative complications. Chen et al. (2011; S23) reported that the decline of cognitive function after surgery is common and may lead to increased mortality. This finding was also sustained by Ruiz-Neto, Moreira, and Furlaneto (2002), who report that delirium is a common complication in the postoperative period, being associated with increased postoperative mortality and morbidity. Therefore, with regard to cognitive function, the delivery of specific care, including therapeutic cognitive activities (orientating communication and cognitive stimulation activities, etc.) reduces postoperative delirium rates (S23).

In addition, in S23, Chen et al. (2011) found that care protocols reduced functional decline. Early mobilization and nutritional assistance contributed to a significantly lower decline in the patients' performance of activities of daily living and nutritional status. Sands (2007) shared this opinion, and emphasized that early mobilization after surgery is essential for the prevention of several complications because of the sharp decline in the self-care ability faced by gastric cancer patients.

Sands (2007) also mentioned that these patients are at risk of having postoperative complications in the digestive system, including gastric reflux, dumping syndrome, among others. So, nurses play a key role in making the necessary changes to the patients' diet and providing education on eating strategies in order to minimize potential disorders and nutritional decline.

Similarly, Park and Park (2010) emphasized the importance of guidelines for the prevention, detection, and early intervention in possible postoperative complications such as bleeding, reflux gastritis, and dumping syndrome, as well as the reduction of disparities specific to nursing care delivery.

\section{Promotion of self-management skills and quality of life improvement}

Educating gastric cancer patients through interactive programs proved to be more effective in terms of the patient's disease-related knowledge in the short- 
(hospitalization) and long-term (6 and 12-month follow-up), such as coping with the disease in the short-term, when compared with an information-only program (Faller, Koch, Reusch, Pauli, \& Allgayer, 2009; S27). Both programs were informative and had the same contents. The main difference was the amount of interaction allowed among patients and between patients and the educator.

In the interactive program (S27), patients were encouraged to ask questions and were in turn asked questions by the educator to promote a deeper understanding of the information presented. Patients were encouraged to link the information with their personal situations, thereby increasing their knowledge about their condition/disease and on how to cope with the illness, reinforcing the importance of the patients' interaction/participation in their care. Melo (2005) argues that informing and engaging patients, i.e. allowing interaction between the health professional and the patient, contributes to satisfy different needs, namely: "Facilitates coping with the disease, enhances the acceptance of the procedures, increases commitment and compliance, and leads to respect and dignity preservation" (p. 58). In this line of thought, Wittmann et al. (2011) mention that providing adequate information improves the patients' psychological well-being and enables them to develop strategies to cope better with their condition and develop their ability to self-manage the disease and its implications.

In S27, Faller et al. (2009), using the Gastrointestinal Life Quality Index (GLQI) which covers gastrointestinal symptoms, emotional well-being, physical function, social function, and medical treatment concluded that the group that received an interactive program reported a higher quality of life than the group that received the basic information program, in which no interaction was allowed between patient and educator. This difference in the results was only observed during hospitalization and not in the long term (6and 12-month follow-up). This may be due to the fact that the program was only implemented during hospitalization and not during the follow-up period.

Several authors corroborate the abovementioned data, including Santos and Fuly (2014), who argue for the need of a comprehensive patient care that includes not only hospital care, but also follow-up outside of the hospital (e.g., home visits), in order to ensure the patients' autonomy and quality of life.
Malmstrom, Ivarsson, Johansson, and Klefsgard (2013) described cancer patients' experiences after surgical treatment in terms of their quality of life and ability to cope with their new situation. The results of the study showed that a supportive care program which encompasses care delivery is necessary to meet the patients' needs, particularly their physical, psychological, and social needs during diagnosis, treatment, and follow-up. Mello et al. (2010) believe that a multidisciplinary intervention, capable of addressing the patient as a whole, can improve postoperative outcomes and quality of life.

\section{Conclusion}

The issue addressed in the question "Which nursing interventions/programs are more effective in the postoperative recovery (fewer complications, increased self-management skills, and improved quality of life) of gastric cancer patients undergoing surgical treatment?" is of great interest, and the results found in this study can inform nursing practice. This SLR identified some effective nursing programs/interventions in the postoperative recovery of people with gastric cancer, including: Modified HELP Program, which consisted of early mobilization, nutritional assistance, and therapeutic cognitive activities; Interactive Information Program, whose information content included, risk factors for gastric cancer, treatment, and postoperative complications, etc. Some results found in the included studies support the effectiveness of nursing interventions in the postoperative recovery of people with gastric cancer. With regard to the reduction of postoperative complications, we observed a lower functional decline in the performance of activities of daily living and in nutritional status, and the improvement of the cognitive function and surgical outcomes. As regards self-management skills, patients improved their level of knowledge about their condition/disease in the short- and long-term, as well as their ability to cope with the illness in the short-term. Patients' quality of life and well-being in the physical (improvement of gastrointestinal symptoms), emotional, and social domains improved during hospitalization.

This SLR has some limitations and weaknesses. One of the limitations is the heterogeneity of the included studies, which made it impossible to conduct a meta- 
analysis and hindered the generalization of the results. Another limitation was the inclusion criterion related to the language of publication (only studies written in Portuguese, Spanish, and English were included), which may have contributed to the exclusion of potentially relevant studies. The fact that the search was performed based on title and abstract using keywords and a few synonyms, with no truncation in the search strategy, may have also contributed to the exclusion of potentially relevant studies. However, the expected objectives were achieved. The results obtained have implications for care delivery, particularly due to their contribution to the justification and redefinition of perioperative nursing interventions in gastric cancer patients undergoing surgery. Furthermore, they offer a valuable contribution to these patients' recovery, reducing complications and improving their disease self-management skills and quality of life. In terms of research, it should be emphasized that further randomized studies are needed to enhance the current evidence on the topic under analysis, confirm/reinforce these results and/or explore the effectiveness of these interventions in other care dimensions with the purpose of improving health outcomes.

\section{References}

Ahn, H. S., Yook, J. H., Park, Ch. H., Park, Y. K., Wansik, Y., Lee, M-S., ... Yang, H-K. (2011). General perioperative management of gastric cancer patients at high-volume centres. Gastric Cancer, 14(2), 178-182. doi:10.1007/s10120-011-0012-x

American Cancer Society. (2014). Stomach cancer. Retrieved from http://www.cancer.org/acs/groups/cid/documents/ webcontent/003141-pdf.pdf

Araújo, D. (2014). O efeito da utilização da chupeta na prevenção do síndrome de morte súbita do lactente: Uma revisão sistemática da literatura com meta-análise (Dissertação de mestrado). Retrieved from http://comum.rcaap.pt/ bitstream/10400.26/9502/1/Disserta\%C3\%A7\%C3\%A3O_ Denise1851.pdf

Chen, C. C., Lin, M.T., Tien, Y. W., Yen, C. J.,Huang, G. H., \& Inouye, S. K. (2011). Modified hospital elder life program: Effects on abdominal surgery patients. Journal Of The American College of Surgeons, 213(2), 245-252. doi:10.1016/j.jamcollsurg.2011.05.004

Diaz-Nieto, R., Orti-Rodríguez, R., \& Winslet, M. (2013). Postsurgical chemotherapy versus surgery alone for resectable gastric cancer. Cochrane Database of Systematic Reviews, 9. doi:10.1002/14651858.CD008415.pub2
Faller, H., Koch, G. F., Reusch, A., Pauli, P., \& Allgayer, H. (2009). Effectiveness of education for gastric cancer patients: A controlled prospective trial comparing interactive vs. lecturebased programs. Patient Education \& Counseling, 76(1), 9198. doi:10.1016/j.pec.2008.11.021

International Agency for Research on Cancer, World Health Organization. (2014). Helicobacter pylori eradication as a strategy for preventing gastric cancer. Retrieved from https://www.iarc.fr/en/publications/pdfs-online/wrk/wrk8/ Helicobacter_pylori_Eradication.pdf

Joanna Briggs Institute. (2011).Joanna Briggs Institute reviewers' manual 2011 edition. Retrieved from http://joannabriggs. org/assets/docs/sumari/reviewersmanual-2011.pdf

Joanna Briggs Institute. (2014). Joanna Briggs Institute reviewers' manual. Retrieved from http://joannabriggs.org/assets/ docs/sumari/reviewersmanual-2014.pdf

Laporte, A. G., Weston, A. C., Paludo, A. O., Castria, T. B., \& Kalil, A. N. (2014). Análise epidemiológica dos adenocarcinomas gástricos ressecados em um serviço de cirurgia oncológica. Revista da AMRIGS, 58(2), 121-125. Retrieved from http:// www.amrigs.org.br/revista/58-02/005.pdf

Malmstrom, M., Ivarsson, B., Johansson, J., \& Klefsgard, R. (2013). Long-term experiences after oesophagectomy/ gastrectomy for cancer: A focus group study. International Journal of Nursing Studies, 50, 44-52. Retrieved from http://www.journalofnursingstudies.com/article/S00207489(12)00284-2/pdf

Mello, B. S., Lucena, A. F., Echer, I. C., \& Luzia, M. F. (2010). Patients with gastric cancer who have undergone gastrectomy: An integrated review. Revista Gaucha de Enfermagem, 31(4), 803-811. Retrieved from http://www.scielo.br/pdf/rgenf/ v31n4/a26v31n4.pdf

Melo, M. (2005). Comunicação com o doente: Certezas e incógnitas. Lisboa, Portugal: Lusociência.

Park, M., \& Park, H. (2010). Development of a nursing practice guideline for pre and post-operative care of gastric cancer patients. Healthcare Informatics Research, 16(4), 215-223. Retrieved from http://www.ncbi.nlm.nih.gov/pmc/articles/ PMC3092132/.

Pereira, A. L., \& Bachion, M. M. (2006). Atualidades em revisão sistemática de literatura, critérios de força e grau de recomendação de evidência. Revista Gaúcha de Enfermagem, 27(4). Retrieved from http://seer.ufrgs.br/ RevistaGauchadeEnfermagem/article/view/4633

Ruiz-Neto, P. P., Moreira, N. A., \& Furlaneto, M. E. (2002). Delírio pós-anestésico. Revista Brasileira de Anestesiologia, 52(2), 242-250. Retrieved from http://www.scielo.br/scielo. php?pid $=$ S0034-70942002000200013\&script $=$ sci_arttext

Sands, J. K. (2007). Problemas de estômago e duodeno. In F. D. Monahan, J. J. Sands, N. Neighbors, J. F. Marek, \& C. J. Green (Eds.), Phipps enfermagem médico-cirúrgica: Perspectivas de saúde e doença ( $8^{\mathrm{a}}$ ed., Vol. 3, pp. 1237-1272). Loures, Portugal: Lusociência. 
Santos, M. G., \& Fuly, P. S. (2014). Visita domiciliar e educação em saúde, promovendo qualidade de vida em pacientes oncológicos. Revista de Enfermagem UFPE On Line, 8(4), 904-909. doi:10.5205/reuol.5829-50065-1-ED-1.0804201415

Wittmann, E., Beaton, C., Lewis, W. G., Hopper, A. N., Zamawi, F., Jackson, C., . . C Crosby, T. D. L. (2011). Comparison of patients' needs and doctors' perceptions of information requirements related to a diagnosis of esophageal or gastric cancer. European Journal of Cancer Care, 20, 187-195.

Yamamoto, M., Rashid, O. M., \& Wong, J. (2015). Surgical management of gastric cancer: The east vs west perspective. Journal Gastrointestinal Oncology, 6(1), 79-88. doi:10.3978/j.issn.2078-6891.2014.097 
